\title{
Form And Substance In Islamic Finance: Analysis of Deferred Payment Sales
}

\author{
Mohidin Yahya Shamsudin ${ }^{\mathrm{a}}$, Hussin Salamon ${ }^{\mathrm{a}}$, Mohd Fauzi Abu-Hussin ${ }^{\mathrm{a}}$ \\ ${ }^{a}$ Faculty of Islamic Civilization, Universiti Teknologi Malaysia, 81310 UTM Johor Bahru, Johor. \\ *Corresponding author:hjmohidin@maijurus.com
}

\section{Article history}

Received: $2014-08-27$

Received in revised form: $2014-10-28$

Accepted: 2014-10-28

\begin{abstract}
Deferred payment contracts involving use of al-bai' bithaman ajil, al-murabahah and bai' al-inah have been extensively used in design of Malaysian in Islamic financial products. It is widely argued that Islamic banking is the replication of conventional system by imitating the conventional banking products excepting that they are presented in syariah compliance mechanism. The deferred payment sales are one of the example. The issues of form and substance in Islamic banking products and instruments has been frequently debated. Therefore, this paper endeavour to analyse the nature and content of Islamic financial products with particular reference to the debt-based transactions of Al-Bai' Bithaman Ajil, Al-Murabahah and bai' al-inah as practiced in the Malaysian Islamic banking. By analysing legal documents, reports, fiqh and Islamic jurisprudence's views, this paper suggests that the debt-based transactions have been proven to be a reliable and efficient way of conducting commercial transactions which are in conformity with the syariah. Nevertheless, the practice of these modes of transactions ought to be enhanced and perfected to avoid intentional or unintentional deception in its implementation.
\end{abstract}

Keywords: Islamic Finance, Deferred payment sales, Analysis. 


\subsection{Introduction}

In the last four decades Islamic banking and finance has witnessed a phenomenal growth in terms of numbers of institutions offering Islamic banking and finance as well as its volume of business. It was recorded that, in 2008 the volume of business of Islamic banking has reached USD951 billion (Hanif, 2011) with total numbers of institutions accounted for more than 550 Islamic Financial Institutions (IFIs) operating in more than 75 countries (Dusuki, 2012). It is expected that with the enormous wealth generated from oil and gas in the west Asian countries and the growing population in the Islamic countries the demand for syariah compliance banking facilities remains strong in the coming years.

The Islamic banking and finance operations is unique in that it is based not on interest charging as practiced by the conventional system but on doing trading and sharing of profit and loss. For Muslim this kind of banking activities are indeed a refreshing welcome as they now have an avenue to do transactions that are in line with the syariah and they are able to abide by the command of Islam in all aspects of their life including business activities. The Islamic system has also attracted the attention of non-Muslim due the fact that Islamic banking has demonstrated its capability to offer an efficient and viable alternative system of banking and finance (Askari, 2009).

Despite the vibrant and dynamic progress achieved by Islamic banking and finance system, it is however, not immune to criticisms both from the opponents as well as proponents of the system. Critique argues that Islamic banking is the replication of conventional system. The products offered by the Islamic banking are the imitation of conventional banking products excepting that they are presented in syariah compliance mechanism but in reality it is a way of circumventing the syariah rule prohibiting riba and rendering it as mere nomenclature. Therefore, it can be said that Islamic financial transaction are conforming to Islamic law in form but failing to meet its substance and spirit (Ahmed, 2010). The issues of form and substance in Islamic banking products and instruments has been frequently debated particularly when there is legal dispute arising between clients and the Islamic financial institution and concern were raised when the court ruled that such products are non-syariah compliance.

It is on this premise that this paper attempt to analyse the nature and content of Islamic financial products with particular reference to the debt-based transactions of Al-Bai' Bithaman Ajil, Al-Murabahah and bai' al-inah as practiced in the Malaysian Islamic banking.

\subsection{Islamic Banking and Finance in Perspective}

Islamic banking and finance refers to the transactions, operations and services that are conducted based on the law of syariah; the Divine Ordinance from the Law Giver consisting of eternal divine will that carries and embodies Allah's instruction and expectation of its human creation and embodies the sum total of Islamic teachings and system in all aspects of human life (n.a. 2009). It is a system of ethics and value covering all aspects of human life encompassing personal, social and political and business undertakings. It reflects the holistic view of Islam which should be looked upon not in isolation but all-encompassing the whole spectrum of human activities (Ahmed, 2009). In other words, Islamic banking is part and parcel of Islamic doctrine which is both the intellectual system and a way of life (Adam, 2006).

The most important objective of syariah in business undertakings is to seek justice and alleviating hardship to the affected parties. Islamic finance and banking seek to promote mutual support and cooperation in its pursuit of realizing maslahah or the public interest. Obviously therefore, Islamic finance operations and activities encompass a broader meaning and frameworks as compared to conventional system which is to seek the all-important wealth maximization. They differs greatly not only in the way Islamic finance conduct its business practices but above all the value that guide the entire operations of Islamic banking. The value that is embodied in the maqasid al-syariah, which is to be translated in every 
syariah compliance transactions not only its legal forms but also in spirit and substance or the intent of all the contracting parties.

Islamic banking has the same purpose as conventional banking in that it function as the mobiliser of funds from the surplus sector to the deficit sector of the economy and providing financial assistance to those in need of such financial facilities to carry out their business. However, Islamic banking differs from the conventional banking in that it follows the rule of fiqh muamalat in its operations. To comply with the provision of syariah, Islamic banking and finance must avoid at all cost the prohibition of riba in all its business operations. Al-Quran treats riba in a very special circumstance. It is not only associated with the material and ephemeral wealth that can increase or decrease through receiving and paying of interest but also the serious repercussions that riba can cause to mankind. Allah has revealed that riba is haram and repugnant to Islam because it involves oppression and unethical conduct of business as those who are wealthier impose undue burden to the less fortunate who are in dire need of help. The practice of interest entails the existence of greed and devouring of other's property in a wrongful and unjust way (Qal'ahji, 2005).

Due to the serious repercussion of riba to all mankind, Allah decided to prohibit it in all our daily business transactions. The prohibition of riba is proclaimed in various different revelations in the Al- Quran. It was first revealed in surah Al-Rum verse 39 which emphasises that interest deprives wealth of God blessing. Then in surah Al-Nisa verse 162 Allah condemns interest, placing it in juxtaposition with wrongful appropriation of property belonging to others. However, the most significant and all-encompassing revelation which clearly sealed all doors to interest is in surah Al-Baqarah verse 275 that "Those who devour usury will not stand except as stands one whom The Evil One by his touch hath driven to madness. That is because they say: "Trade is like usury," But Allah hath permitted trade and forbidden usury. Those who after receiving direction from their Lord, desist, shall be pardoned for the past; their case for Allah (to judge); But those who repeat (the offence) are companions of the Fire; they will abide therein (forever)" (Yusuf Ali, 1994). In this verse Allah s.w.t. has manifestly articulated that Muslim are free to undertake trade transaction or to indulge in sale and purchase contract to fulfil their financial requirements but certainly they must avoid transaction that involve elements of riba.

In essence Islam prohibits Muslim from taking and paying interest (riba) regardless of the purpose for which such transaction or loans are made and regardless of the rates at which interest is charged. Muslim need no further proof before they reject the institution of riba because when there is evidence (nas) from Al-Quran on a subject matter, no human explanation is necessary but to accept the dictum because there is limitation in human reasoning and that the rule is absolute and final. It is therefore, unthinkable for Muslims who know the seriousness of the sin of riba in the sight of Allah to undertake such activities or to continuously indulge in it. Islamic banking and finance is not to indulge in interest based transactions as practiced by the conventional banking but to embrace on undertaking trade transactions and investments which are free from the elements of riba and other syariah injunction of gharar and maysir.

\subsection{Business of Islamic Banking and Finance}

The injunction on riba means that Muslims are not permitted to involve in riba or usurious activities. It means that Muslims are also discouraged from having any business dealings with the conventional banking as all Muslim jurists in Malaysia and elsewhere in the world consider the prevailing banking system unacceptable to Syariah. However, in the modern financial world, interest is the pillar of the system and Islamic finance and banking are not permitted to undertake. Under the circumstances therefore, how will then Islamic bank operate. In Islam, the financial instruments that can be used for trade and production purpose must be based on risk/profit sharing as a return for the entrepreneurial efforts and financial capital (Iqbal, 2011). There are verities of Islamic contracts that can be used but according to Lewis and Algaoud (2001) three of them are the most widely used in Islamic finance namely trustee contract (mudharabah), equity contract (musharakah) and debt-based transactions. 
Al-Mudarabah is a contract between provider of capital (rab al-mal) and an entrepreneur (mudarib). In essence, this contract signifies the willingness of the capital owner to provide capital to the mudarib enabling him to undertake the project. Under the agreement, the mudarib is allowed to utilize the fund for its project. Profit is distributed according to agreed ratio between owner of capital and the mudarib while losses are entirely borne by the (capital owner) rab al-mal. Other salient features of mudarabah are;

1. The owner of capital cannot interfere with the running and operation of the project.

2. Liability of rab al-mal is limited to the amount of capital invested.

3. The fund cannot be utilized for unlawful activities or contrary to Islamic muamalat.

4. The mudharib cannot commit investment in excess of the fund provided.

5. Profit to be distributed after taking into consideration all liabilities of the project.

Al-Musyarakah or shirkah is a contract of partnership between two or more parties to undertake a project or business venture. Under this agreement, each of the partners are to contribute capital and involve in the management of the company. Profit from the ventures are to be distributed according to the agreed proportion while losses if any would be shared by the partners based on the capital contributions to the company. As a general rule under al-musyarakah, neither rab al-mal nor the mudharib can ask for any guarantee on the profit amount to be distributed while liabilities on each of the partners are limited to the level of capital contribution.

Other forms of contracts that can be used in Islamic finance are;

1. Contract of safe custody; al-wadiah

2. Contract of works; istisna and al-wakalah

3. Contract of securities; al-rahn, al-kafalah and al-hiwalah.

Those contracts are valid and permissible under Syariah because they demonstrate the true intention of the contracting parties while its legal forms contains term and conditions that reflect the true nature of these transactions. Indeed the first two contracts are by all counts the most acceptable and ideal form of Islamic transaction because these transactions are asset-based and entail real economic activities while simultaneously undertaking responsibilities or liabilities (Usmani 2005, Ayub 2010, Dusuki 2012). Under mudharabah and musharakah contracts, the transactions are based on profit and loss sharing between the contracting parties, an arrangement that ensure equitable distribution of risks and reward and preclude the unjust accumulation of wealth. They both demonstrate clearly the form of partnership and the intent of all the contracting parties in the partnership. Islam encourages it followers to engage in real economic activities before they can reap the profits from the ventures. Islam abhors those who expect to gain from his investment without taking or assuming any risk as in the case of interest charging activities which place the rich always at the most advantaged position to reap high profit. Indeed musharakah has a tendency to favour the common people rather than the rich only (Usmani 2005).

\subsection{Debt-Based Mark-up Transactions}

Despite the acknowledgement of most Islamic scholars on mushrakah and mudharabah contracts as the most ideal Islamic financing modes, the Islamic banking and finance all over the world have shown their preferences and overconcentration towards another form of financing methods which is debt-based transactions. This method of financing is the deferred payment sales or fixed return contracts of al-Bai' Bithaman Ajil (BBA), al-murabahah and bai' al-inah. In the context of Malaysian Islamic banking and finance, these forms of financing constitute more than $80 \%$ of the total assets held by the Islamic banks (Dusuki, 2012). The trend is symmetrical in most Islamic countries where these methods of financing constituted between $60 \%$ and $80 \%$ of their total assets holdings. Essentially these modes of financing involve deferred payment contracts where customers are allowed to pay the purchased goods on periodical instalments within a specified future period of time. 
Al-Bai' Bithaman Ajil (BBA): also known as bai' mu'ajjal, is a financing contract for purchase of fixed asset like residential houses, office complexes or landed properties. In Malaysia, BBA agreement is used to finance long term contract of up to twenty years which is the norm of home purchases. BBA involve two separate agreements the first being the purchase agreement between the bank and the customer or developer where the bank pay cash for the purchase of the house. The other is the sale agreement between the bank and the customers where the bank sale price is determined to include profit margin for the bank over and above its purchase price. The customer is allowed to defer payment of the sale price on periodical instalments until the sale price is fully satisfied. Unlike the conventional housing loan, the bank sale price is fixed until the maturity of the agreement. Furthermore Islamic banks are not allowed to impose penalty on the late payment of instalment and it is also the practice of Islamic bank to grant an ibra' or rebate for early settlement of the BBA agreement.

Al-Murabahah: is a trust sale transaction between customers and financier where the deferred payment price is to include profit margin for the bank or financier (El Diwany 2010). It is a sale, not loan and it should fulfil certain conditions before it can be regarded as legitimate transaction. In murabahah sale, the mark-up is expressly disclosed to the purchaser how much cost he has incurred and how much profit he is going to earn over and above the cost (Dusuki, 2012). It is indeed a unique feature of murabahah transaction as it is a trust-based contract and therefore, everything should be disclosed to the buyer including the cost price and mode of payment. The sale price is to be paid on a future period and the customer can effect a balloon payment at the maturity of the contract. While BBA is used for long term deferred payment contract, murabahah on the other hand is being utilised by Islamic banks in Malaysia to finance short term trade financing contract of up to a maximum period of 180 days and while payment of BBA is on instalments, Al-murabahah contract is usually settled in one lump sum amount at the end of the contract period although it can be paid by instalments. In essence, both the BBA contract and murabahah are almost identical in nature as practiced by Islamic bank in Malaysia. The term and condition governing both the contracts are similar and they are both regarded as debt-based transactions.

Originally al-murabahah and BBA are not exactly the mode of financing but a simple sale transactions. However, as our Islamic financial system is still, at its infant stage and in order to realise the maqasid alsyariah in banking and finance, the contemporary scholars have allowed both contracts to be used as financing modes subject to a very stringent procedures. The most essential elements of murabahah and BBA are that the goods must remain in possession of the financier prior to the sale to customer (Usmani, 2005, pp108). In other words, it means that the financier would have to take the ownership risk albeit for a short period. According to Ahmed (2011), it is common that in a true sale transaction under al-murabahah and BBA, bank may incur ownership risk in three different stages namely;

1. Beginning of transaction: bank buys assets based on promise from the buyer. However, promise is not binding and if the customer declines to honour his promise bank may get stuck with the asset and be exposed to market risk as price may fluctuate. Any loss during this stage is borne entirely by the bank.

2. Transaction period: once asset is transferred to the client bank may face credit risk. This is especially true if payment is made on instalments. To mitigate this risk, bank may request that the asset be collateralised to guarantee performance of the agreement by the customer.

3. End of period: Upon expiry of the agreement bank may still face with potential problem if customer fails to satisfy the payment to the bank. In this instance bank may initiate court order to compel customer to honour the agreement failing which a court order is required to farce sell the property to cover the shortfall.

The ownership risk is the only feature of murabahah and BBA that differentiate it from the conventional interest based transaction thus ensuring its validity and permissibility from the perspective of syariah. Some other issues relating to bai' al-murabahah and BBA are that they are credit sale where the mark-up is determined by applying the interbank money market rates which is akin to the conventional 
pricing for loan and that some Islamic financial institutions used this method to include financing items such as overhead cost or that the financing without genuine underlying asset involved which is prohibited (El-Diwany, 2010).

Bai' Al-Inah: conceptually it refers to sale of an asset, which is later repurchased at a different price, whereby the differed price is higher than the cash price (BNM, 2007). Technically bai' al-inah is when a person sells its assets to another person or financial institution for cash and immediately repurchases it from the buyer at higher price to be paid at a future date usually on instalments. The Malaysian Islamic banking employs this contract to grant a personal loan or providing a credit card facility to its clients. Most Islamic scholars regard bai' al-inah as a legal stratagem to circumvent syariah prohibition on riba. Accordingly, Imam Abu Hanifa, Al-Shafie and Ibn Hazm are of the view that the validity of a transaction is determined by its expression or its form while the intentions of the contracting parties are not to be considered unless it is expressly declared (Dusuki 2012).

Bai' al-inah is widely practiced in Malaysia and Brunei in their Islamic banking system which is used in personal financing and credit card facilities. However, the validity of bai' al-inah is still a matter of disagreement amongst syariah scholars based on their own interpretation and justification. Ibn Rusd in his book Fatwa Ibn Rusd states that the applicable method of prohibiting this transaction serves the purpose of sadd al-dharai'ah means blocking the lawful means to an unlawful end (BNM, 2007). Imam Hanafi was of the opinion that bai' al-inah is permissible only if it involves a third party, which acts as an intermediary between the seller and the buyer while Imam Malik and Hambal on the other hand rejected this type of transaction and considered it as unlawful and invalid contract (Hassan, 2011). Their opinion is based on the principle of sadd al-dharai'ah and the saying of Saidatina Aishah. It is narrated that, Aishah encountered with a woman who had sold a slave belonging to Zaid Bin Arqam to Ata' at 800 dirham and since Ata' need some cash she bought back the slave at 600 dirham to which Aishah replied " how could you execute such a bad sale? You should inform Zaid bin Arqam that his conduct has extinguished all his reward for participating in jihad with the Prophet s.a.w. if he does not repent (BNM 2007). However, Imam Al-Shafie in his book Al-Umm opined that if we are going to assume that someone's sale and purchase is forbidden whereas he believes that the contract is permissible, we are not allowed to judge his past good deeds as have been wiped off by Allah s.w.t. The saying of Saidatina Aishah regarding the transaction even if it is authentic and accepted, is not her ijtihad and certainly is her own opinion and not the saying of the Prophet Mohammad (s.a.w) himself and therefore cannot be the basis of Islamic law (BNM, 2007). Thus according to Imam Al-Shafie, bai' al-inah is a legitimate trade transaction from the perspective of syariah.

Indeed there are hadiths which prohibit bai' al-inah transaction. One such hadith is that the Prophet s.a.w. said "if you sell and purchase based on inah, and you cultivate, and you are satisfied with the cultivation, and you ignore the duty to do jihad, Allah s.w.t. will curse you and He will not remove the spell until you return to your religion." (Narrated by Sunan Abu Daud). As for Islamic banking in Malaysia, the Syariah Advisory Council of Bank Negara Malaysia has resolved on its $8^{\text {th }}$ meeting held on December 12, 1998 that bai' al-inah transaction in the Islamic Interbank Money Market is permissible on condition that it must strictly follow the mechanism which is accepted by Shafie school of thought (madzhab) and the transacted asset is not ribawi items (BNM, 2007). It appears therefore, the legal form of bai' al-inah is a matter of juristic disagreement among syariah scholars backed by their own basis of justifications. As for Malaysia, the inah concept is accepted to ensure that Islamic finance is as competitive as its conventional counterpart (BNM, 2007). Nevertheless, recent trend shows that, some of major Islamic banking in Malaysia has utilised bai' al-tawarruq concept rather than bai' al-inah.

The above mentioned transactions invariably involve buying and selling of commodities between bank and its client. Details of the contracts follow the syariah requirements which are clearly manifested in the term and conditions of the contracts that bind both the contracting parties. Interestingly these terms and conditions are adopted based on the rules and procedures of the syariah governing trade transactions. Most notable in the terms are that the contract is a sale contract and not financing agreement as in the case of 
conventional loan agreement. The selling price of the goods is clearly indicated in the agreement and is binding to the contracting parties.

Other major features of these transactions are;

1. The transactions are asset-based involving real economic activities. The bank is selling goods to its client on a differed payment with mark-up which represents the bank's profit margin in the transaction. The asset is entrusted to the bank as collateral against nonpayment of the selling price and non-fulfilment of other obligation under the contract.

2. Bank is invariably the owner of the assets albeit for a short period of time before it is transferred to the client. Therefore, bank assumes ownership risk and not mere financing the acquisition of assets as in the conventional banking.

3. There is clear prohibition in dealing with assets and activities that are not allowed under the syariah. It means that a bank need to ensure that asset is halal and it is not to be used for activities that are prohibited in Islam.

4. The ownership risk is covered by the insurance policy indemnifying both the bank and client in the event of unforeseen circumstances during the tenure of the contract.

\subsection{Complying with the Syariah}

The Syariah compliance in Islamic transactions or muamalat goes beyond mere legal from and the words or structure of the underlying contracts. It transcends the very intent of the contracting parties and the objectives and the purpose of such transactions. Underpinning the totality of Islamic contract, syariah gives due emphasis on the substance of the contract or the true intent of the contracting parties and the real objective of such transactions while not negating the importance of the relevant legal forms. While legal form of a contract is relatively easy to be recognised, however, determining the substance of a contract is not as simple as it is presumed to be. This is because as Imam al-Shafie opined, the intention of contracting parties are inside the heart and mind of the person and it is between him and Allah s.w.t. so it is not for other people to judge and determine. According to him it is impractical to determine the validity of contracts by means of intention as it is difficult and sometime impossible to identify the intention of the contractor (Dusuki, 2008).

The rigor of test on the validity of any contract occurs when there is an unfortunate circumstance affecting the enforcement of the contract. This happen normally when the customers fail to fulfil their obligations under the agreements and the bank sought the court declaration to demand payment of periodical instalments or to recover the facilities. In the context of the Malaysian Islamic banking, since 1994 there have been several cases that had been adjudicated by the court. Most of the court cases were related to the BBA contracts but none were from bai' al-inah and al-murabahah transactions. The reason from nonexistence of cases on al-murabahah is perhaps in Malaysia the murabahah facility is granted mainly to traders to finance their purchase of inventory and working capital. The facility is also for short term period when under normal condition traders would have been able to sell off its merchandise in time to repay the murabahah financing.

In the context of Malaysian Islamic banking and elsewhere in the world, the most competent medium to ascertain the form and substance of Islamic transaction agreement is the civil court because in as far as Islamic banking in Malaysia, the administration and interpretation of banking regulations including the Islamic Banking Act 1983 is under the auspices of the Civil Court of Malaysia and not the syariah court. The role of civil court as the interpreter of term and condition of a contract is also shared by the civil courts in other Islamic countries such as Dubai. This has been demonstrated in the court of Dubai involving case under ijarah contract. Although the case is related to ijarah financing, the court however, had shown its true authority and competence in defining the intent of the contracting parties to the agreement. The court ruled that although the primary agreement is ijarah agreement, the court rule that it is a simple case of buy 
and sell transaction. The court interpreted the intention of the contracting parties in that despite the existence of ijarah contract, both the plaintiff and defendant entered another contract or undertaking to buy and sell the good upon expiry of the primary lease period. The court accordingly ruled that it is a sale and purchase transaction as intended by both parties (Suruhanjaya Sekuriti Malaysia, 2010).

In the case of BIMB v Adnan Omar [1994] 3 CLJ 735, the bank granted the plaintiff a loan to purchase a house under the concept of BBA. The bank purchase price is RM265, 000 and when the asset is sold to the customer on a deferred payment basis, the selling price was fixed at RM583, 000. After four years period the defendant defaulted and fail to honour his obligation under the agreement. The court held that the defendant was bound to pay the whole sum of the bank's selling price under the agreement on the ground that he knew the terms and conditions of the contract and knowingly and on his free will entered into the agreement. The court also ruled that the intention of the bank was to grant a financing facility under the concept of BBA and therefore bank is entitled to claim the full sum of the selling price as per the BBA Agreement. The court in this case did not look into the issue whether the BBA contract involved disapproved elements by syariah as stipulated in the Islamic Banking Act 1983 or the Banking and Financial Institutions Act 1989. This is because no reference was made to the Syariah Advisory Council of BNM which is the highest authority in as far as Islamic banking operations is concerned. The court felt there is no necessity to refer to any other competent forum since the court is to decide the case based on the facts and terms of the agreement according the practice of common law.

The subsequent case related to BBA contract was between Affin Bank and Zulkefli Bin Abdullah [2006] 3 MLJ 67. In this case the learned Judge Abd Ghani Patail questioned the very intention of the bank because it imposed two selling prices for the same property in a single contract. The first selling price was lower because at the material time the defendant was still an employee of the bank, it is customary for bank to grant advance ibra' to its employee under the Staff Home Ownership Scheme. However, when the defendant left the service of the bank, the selling price was revised by the bank and fixed new price which is far higher than previously determined. The court question the bank as to the intent of the bank under the agreement. In this case the court held that the Islamic contract of BBA is similar to the conventional loan and hence the Islamic bank cannot claim the unearned profits because it was equal to interest calculation. The court opined that the proper approach is to examine further the practice of Islamic banking as to whether or not that the BBA facility is contrary to the Islamic law.

The issue of substance in BBA agreements was again raised by the judge in the case involving Arab Malaysian Finance v Taman Ehsan Jaya and Others [2008] 5 MLJ 631. Most of the cases brought before the court is to determine the amount of claim that entitled by the bank under the agreement in the event of customers' default. The judge in this case ruled that where the bank recalls the BBA facility at a higher price in total, the sale is not a bona fide sale but a financing transaction and therefore, it renders the BBA facility contrary to the Islamic Banking Act 1983 and the Banking and Financial Institution Act 1989.

It is interesting to note that in various BBA cases, the bank showed no pretention to its role as a financial intermediaries and showed total reluctance to deviate from the terms of the contracts. The banks' overemphasis on the terms of the contract has diminished the intent of the parties in the agreement which is a bona fide sale transaction. This has been demonstrated by the court ruling that for all intent and purposes and in so far as the BBA agreement is concerned the bank is actually extending a financing facility to the customer and not conducting actual sale transaction.

In the BBA cases thus far, the bank clearly reflected its position as the financier rather than a trader in the true sense of the word. The terms and conditions of the contract were constructed in such a way that the bank will always has the advantage over the clients to recover the facility given under the BBA agreement in the event of default. It seems that under the BBA contract, the intention of the bank is not to do a bona fide sale and purchase but merely providing financing. This scenario occurs could be due to the fact that the BBA agreement is mere adaptation of the conventional housing loan documents. This has been acknowledged by the judge in the case of BIMB v Azhar Osman [2010] 5 CLJ 54 that "the legal documents used by Islamic bank should have addressed the peculiarity of Islamic banking transactions, instead of 
adopting cut and paste approach of the conventional loan documents. If this has been done in a proper manner, the court does not have to interfere with the terms of the agreement or to add implied terms". It could be inferred therefore, that the intention of the bank in the entire BBA transaction was manifestly questionable.

Another issue pertaining to the substance of BBA transaction is that the practice of Islamic bank has greatly diverged from the maqasid al-syariah. Under the BBA principles, the bank is to hold all liabilities arising from defective goods sold based on khiyar al-aib rule but in reality the bank transfers all its risk and liabilities to the customer thereby leaving the bank with no risk while securing profit which is fully guaranteed by way of executing a sale contract with the client (Dusuki, 2008).

As mentioned before, bai' al-inah is a very popular mode of financing in the Malaysian Islamic banking for granting personal loan and credit card facilities. Although there was no reported case that has been brought before the court, the practice of banks in granting this facility to its client may shade some light as to the intent of the contracting parties under the facility. Under the contract, bank is supposed to buy item in cash, sell it to its client on differed payment basis and the client sell it back to the bank at a discount. The customer is then allowed under the agreement to make instalment payment for the bank based on the original sale price. The real intention of this transaction is to enable the client to obtain instant cash. However, the practice of certain banks is that the customer is required to purchase fictitiously on paper an item on credit and then sell it back to the bank at a discount. The customer is then required to pay to the bank the original purchase price on instalments. The intention of this transaction is to enable customer to obtain cash from the bank and the mechanism was used in order to validate the transaction (Mohamad, 2010). The sale and purchase transaction in this deal has never been intended to have taken place. In reality, the bank and the customer were merely accommodating the syariah requirement under bai' al-inah contract to enable the customer to obtain cash. If we look closely the entire transactions of bai' al-inah as practiced by Islamic banks in Malaysia, it seems that the intention of both parties in the agreement were not to do sale transaction but to procure instant cash through lending. Moreover, the practice of Islamic bank in Malaysia is that banks are merely acting as provider of cash to the intended clients without doing the actual trading (Dusuki, 2008). In essence it can be said that the bai' al-inah transaction is lending activity disguise under a buy and sell transaction. Therefore, by mere looking at legal construct of the agreement may not be sufficient to ascertain the validity of transaction form the syariah view point.

Islamic muamalat as intended by the relevant transaction is not only to fulfil the religious requirements but more importantly is to attain the all-encompass maqasid al-syariah which is to seek justice and humanity in business. One the major contention of the BBA transaction is the selling price which is regarded by the court as being excessive and burdensome to the client. In the case of Affin Bank v Zulkefli Abdullah, the judge ruled that it would be unthinkable if a transaction based on Islamic rules and procedures would leave the customer in a more disadvantaged position due to excessive selling price that bank sought to recover from defaulted client even more burdensome as compared to conventional loan with interest. It seems therefore, the debate on forms and substance of Islamic transaction is not mere intellectual discourse as some would have imagined but it encompasses the practical issue which must be addressed by the Islamic banking and finance to ensure that Islamic banking and finance transactions remain viable and acceptable.

\subsection{Conclusion}

The primary goal of setting up Islamic financial institutions is to fulfil Islam as ad-din or way of life which spans the entire spectrum of human activities including business. The existence of Islamic financial institutions enables Muslim to transact business that conforms to the syariah rules. It is not mere legal stratagem to circumvent the syariah injunction prohibiting riba in any business undertakings. Indeed, the Islamic bank in Malaysia which operates alongside the conventional banking system has been well accepted by Muslim and non-Muslim alike as a viable alternative system. The modes of transactions adopted by 
Islamic bank demonstrate not only its compliance to the syariah rule in legal form but also its fairness and justice to its clients, avoiding gharar and uncertainty in its transactions.

The debt-based transactions of al-bai' bithmana ajil, al-murabahah and bai' al-inah have been proven to be a reliable and efficient way of conducting commercial transactions which are in conformity with the syariah. However, the practice of these modes of transactions ought to be enhanced and perfected to avoid intentional or unintentional deception in its implementation which may inflict hardship to the clients. One pertinent point is the current method of setting the sale price under Islamic facility which is identical to a conventional loan need to be revisited so as to a void criticism of exploitation and injustice and is also tantamount to back door to riba.

The requirement of Syariah is not only limited to the legal form of the transaction as reflected in the legal documentation binding the contracting parties in the Islamic transactions. More importantly Islamic business undertaking must also demonstrate the intention of all parties involved in the transactions. Islamic banking must be seen as compassionate in their dealing while at the same time they are also capable of generating income sufficient to give optimum return to the investments. It is equally critical for Islamic banking and finance to have courage to break away from the conventional banking mind set and focus on development and innovation of flagship products that are perceived not as imitation of conventional products but truly conforms to the rule and foundation of syariah both in letters and spirit.

\section{References}

Adam, Mohamad Ibrahim (2006). Islamic Shari'ah Concepts Governing Islamic Banking and Finance, available at: www.dradamlawfirm.com accessed on Nov 72012.

Affin Bank Bhd v Zulkifli Abdullah [2006] 3 MLJ 67: BBA

Ahmed, Habib (2011). Products Development in Islamic Banks, Edinburgh University Press Ltd.: Great Britain.

Arab Malaysian Finance Bhd v Taman Ehsan Jaya Sdn Bhd \& Ors [2008] 5 MLJ 631: [2009] 1 CLJ 419: BBA.

Askari, Hossein, Iqbal, Zamir and Mirakhor, Abbas (2009). New Issues in Islamic Finance \& Economics Progress and Challenges, John Wiley \& Son (Asia) Pte Ltd.: Singapore.

Ayub, Mohamad (2010). Understanding Islamic Finance, John Wiely and Son: London.

Bank Islam Malaysia Bhd (BIMB) v Adnan Bin Omar [1994] 3 CLJ 735; [1994] 3 AMR 44; [1994] 4 BLJ 372:BBA

Bank Islam Malaysia Bhd (BIMB) v Azhar Bin Osman \& Ors [2010] 1 LNS 251: BBA.

BNM (2007). Shariah Resolution in Islamic Finance, Bank Negara Malaysia: Kuala Lumpur

Duski, Asyraf Wajdi (2008). Islamic Finance: An Old Skeleton In A Modern Dress, International Shari'ah Research Academy (ISRA): Kuala Lumpur, Malaysia.

Dusuki, Asyraf Wajdi (2012). Islamic Financial System Principles and Operations, International Shari'ah Research Academy (ISRA): Kuala Lumpur, Malaysia.

El Diwany, Tarek (2010). Islamic Banking and Finance: What It Is and What It Could Be, $1^{\text {st }}$ Charitable Trust: United Kingdom. 
Mohidin Yahya Shamsudin et al. / UMRAN - International Journal of Islamic and Civilizational Studies. vol. 1 no.1 (2014) 11-21

Hanif, Mohammad (2011). "Differences and Similarities in Islamic and Conventional Banking," International Journal of Business and Social Science, Volume 2, No.2 February 2011.

Hassan, Zulkifli and Austay, Mehmet (2011), "An Analysis of Court's Decisions on Islamic Finance Disputes,” ISRA International Journal of Islamic Finance, Volume 3, Issue 2, December 2011.

Iqbal, Zamir and Mirakhor, Abbas (2011), An Introduction to Islamic Finance Theory and Practice, $2^{\text {nd }}$ Edition, John Wiely and Son (Asis) Pte Ltd.: Singapore.

ISRA (2009). Dispute Resolution in Islamic Banking, International Shari'ah Research Academy: Kuala Lumpur.

Lahsasna, Ahcene (2011). Shari'ah Aspects of Business and Finance, International Centre for Education in Islamic Finance (INCEIF): Kuala Lumpur.

Lewis, Mervyn and Latifa Algoud (2001). Islamic Banking, Cheltenham: Edward Elgar Publication UK.

Mohamad, Nik Mahani (2010). Rethinking The Islamic Financial System, SABA Islamic Media: Kuala Lumpur, Malaysia

n.a. 2010, "Islamic Finance: When things Go Wrong" Global Islamic Finance Report, available at: www.aghashamsi.com accessed on: November 022012.

Qal'ahji, Muhammad Rawas (2005). Urusan Kewangan Islam Menurut Perspektif Shari'ah Isalm,(Malay Translation), Al-Hidayah Publisher: Kuala Lumpur.

Suruhanjaya Sekuriti Malaysia (2009). Islamic Capital Market - Islamic Commercial Law (Fiqh Muamalat), Suruhanjaya Sekuriti Malaysia: Kuala Lumpur.

Usmani, Mohamad Taqy (2005). An Introduction to Islamic Finance, Maktab Ma'riful Quran: Karachi, Pakistan.

Yusuf Ali, Abdullah (1994). The Meaning of The Holy Quran, Amana Corporation: Brentwood, USA. 